\title{
Increased expression of CD44v6 in endocrine pancreatic tumours but not in midgut carcinoid tumours
} B Terris, J F Fléjou, S Dubois, P Ruszniewski, J Y Scoazec, J Belghiti, F Potet, P Bernades,
M Mignon, D Hénin
Services d'Anatomie Pathologique, Hôpital Beaujon, Clichy, France B Terris

J F Fléjou

$S$ Dubois

D Hénin

Service de

Gastroentérologie, Hôpital Beaujon P Ruszniewski

P Bernades

Service de Chirurgie Viscérale, Hôpital Beaujon

J Belghiti

Laboratoire de Biologie Cellulaire et INSERM Unité 327, Faculté de Médecine Xavier Bichat, Paris, France

J Y Scoazec

Service d'Anatomie Pathologique, Hôpital Bichat F Potet

Service de

Gastroentérologie, Hôpital Bichat $M$ Mignon

Correspondence to: Dr Benoît Terris, Service d'Anatomie Pathologique, Pothologique, 100 Blvd du Général Leclerc, 92118 Clichy, France.

Accepted for publication 30 May 1996

\begin{abstract}
Aims/background-To analyse the different isoforms of CD44 in various types of endocrine pancreatic and gut carcinoid tumours and to investigate the relation between their expression and tumour dissemination. This study was prompted by the recent observation that inappropriate splicing of the CD44 gene was correlated with tumour progression and metastasis formation in a number of human cancers. Methods-Expression of CD44 isoforms was studied in 38 endocrine pancreatic tumours and gut neuroendocrine tumours using antibodies directed against products of exons v3, v4-v5, v6, v7-v8 as well as against the standard CD44 molecule (CD44H). CD44 gene expression was also analysed by reverse transcription PCR (RT-PCR) in nine endocrine and seven carcinoid tumours.
\end{abstract}

Results-All gastrinomas except one (nine of 10) and about half of the other endocrine pancreatic tumours (seven of 15) expressed CD44v6. Most (10/11) midgut carcinoid tumours were CD44v6 negative, with no detectable immunostaining. CD44v3, CD44v4-v5 and CD44v7-v8 were not expressed in any of these tumours. CD44 mRNA analysis illustrated a complex splice pattern and expression of large CD44 isoforms in CD44v6 positive endocrine tumours, whereas the standard form only was detected in midgut carcinoid tumours. No correlation between CD44 variant expression and tumour metastasis was observed.

Conclusions-CD44 variants encoding exon v6 are preferentially expressed both in gastrinomas and in most pancreatic endocrine tumours. In contrast to other tumours, the expression of CD44v6 in pancreatic neuroendocrine tumours does not seem to be correlated with tumour dissemination.

(F Clin Pathol: Mol Pathol 1996;49:M203-M208)

Keywords: pancreas, neuroendocrine tumours, CD44, alternative splicing.

Neuroendocrine tumours of the gut are uncommon neoplasms with highly variable growth patterns. Traditional histological criteria of malignancy such as nuclear pleomorphism, prominent nucleoli, mitotic activity, infiltrative margins, and vascular invasions, which help to establish prognosis in most human neoplasms, are unreliable in pancreatic neuroendocrine tumours. ${ }^{12}$ A variety of other criteria have been advocated for predicting the behaviour of both pancreatic neuroendocrine and gut carcinoid tumours. Most of these criteria are based on the assessment of the proliferative activity. ${ }^{3}$ Although interesting results have been obtained with DNA analysis for gastrinoma, ${ }^{5}$ the criteria of malignancy remain the presence of metastases to lymph nodes, liver or distant organs and/or invasion of adjacent organs.

In parallel to the determination of the proliferative activity, some studies have reported expression of growth factor peptides and adhesion molecules in pancreatic islet tumours. ${ }^{6}$ These factors may influence both cell proliferation and metastasis. CD44, a widely expressed cell surface glycoprotein, is a hyaluronate receptor and has various isoforms that consist of post-translationally modified products of primary (standard) CD44 (CD $44 \mathrm{H})$ or alternatively spliced (variant) CD44 transcripts (CD44v). The variant isoforms differ from the $\mathrm{CD} 44 \mathrm{H}$ molecule in that they contain additional peptide domains inserted into the membrane proximal extracellular domain. While $\mathrm{CD} 44 \mathrm{H}$ is implicated mainly in cell-cell and cell-extracellular matrix interactions during migration and lymphocyte circulation, some of the variant isoforms are involved in lymphocyte activation and metastases development. CD44v glycoproteins with sequences encoded by exon v6 confer full metastatic potential on rat carcinoma cell lines, which can be blocked by monoclonal antibodies directed against exon $6 .^{78}$ Clinical investigations have shown that different human tumours contain high levels of large molecular weight variants of CD44 corresponding to splice variants. Recent studies indicate that the expression of the CD44v6 epitope seems to be correlated with advanced stages of human breast and colon cancers and aggressive stages of nonHodgkin's lymphoma..$^{9-14}$ These results suggest strongly that certain CD44 splice variants play a major role in tumour progression and particularly in lymphogenic metastatic spread.

To our knowledge there is only one study on CD44 expression in digestive neuroendocrine tumours. ${ }^{15}$ Interestingly, the authors observed strong expression of CD44 and the production of alternatively spliced variants in gastrinoma. All others tumours except one midgut carci- 
Table 1 Summary of clinical data, immunohistochemistry and CD44 splice variant expression in gastrinomas and pancreatic neuroendocrine tumours

\begin{tabular}{|c|c|c|c|c|c|c|c|}
\hline \multirow[b]{2}{*}{ Patient } & \multirow[b]{2}{*}{ Age/Sex } & \multirow[b]{2}{*}{ Primary tumour site and diagnosis } & \multirow[b]{2}{*}{ Metastases } & \multirow[b]{2}{*}{ Tissue examined } & \multicolumn{2}{|c|}{ Immunohistochemistry } & \multirow{2}{*}{$\begin{array}{l}R T-P C R \text { splice } \\
\text { variants } \\
(>880 \mathrm{bp}) t\end{array}$} \\
\hline & & & & & $C D 44 H$ & $C D 44 v 6$ & \\
\hline $\mathrm{G} 1^{\star}$ & $25 / M$ & EPT gastrinoma & Lymph node & $\mathrm{P}+\mathrm{M}$ & +++ & +++ & + \\
\hline $\mathrm{G} 2$ * & $22 / \mathrm{M}$ & Lymph node gastrinoma & Liver & M & +++ & +++ & + \\
\hline G3* & $55 / M$ & Duodenal gastrinoma & 0 & $P$ & +++ & +++ & + \\
\hline $\mathrm{G} 4$ * & $57 / \mathrm{M}$ & Lymph node gastrinoma & 0 & $M$ & +++ & +++ & + \\
\hline G5* & $63 / \mathrm{F}$ & Duodenal gastrinoma & Lymph node + liver & $\mathbf{P}$ & - & - & - \\
\hline G6 & $53 / \mathrm{M}$ & Duodenal gastrinoma & Lymph node & $\mathbf{P}$ & +++ & +++ & ND \\
\hline G7 & $32 / \mathrm{F}$ & Duodenal gastrinoma & 0 & $\mathrm{P}$ & +++ & +++ & ND \\
\hline G8 & $47 / M$ & Duodenal gastrinoma & Lymph node & $P+M$ & +++ & +++ & ND \\
\hline G9 & $60 / \mathrm{F}$ & Duodenal gastrinoma & 0 & $\mathbf{P}$ & +++ & ++ & ND \\
\hline G10 & $76 / \mathrm{M}$ & EPT gastrinoma & Lymph node + liver & $\mathbf{P}$ & +++ & +++ & ND \\
\hline $\mathrm{T} 1$ & $41 / \mathrm{F}$ & EPT insulinoma & 0 & $\mathbf{P}$ & +++ & +++ & ND \\
\hline $\mathrm{T} 2^{\star}$ & $46 / F$ & EPT insulinoma & 0 & $\mathrm{P}$ & ++ & ++ & + \\
\hline T3* & $66 / \mathrm{M}$ & EPT non-functioning & 0 & $\mathbf{P}$ & ++ & - & - \\
\hline $\mathrm{T} 4$ * & $33 / \mathrm{M}$ & EPT non-functioning & Lymph node & $\mathbf{P}$ & ++ & +++ & + \\
\hline T5* & $28 / \mathrm{F}$ & EPT non-functioning & Lymph node & $\mathbf{P}$ & ++ & - & - \\
\hline T6* & $30 / \mathrm{F}$ & EPT calcitonin producing (MEN 1) & Lymph node & $\mathbf{P}$ & ++ & ++ & + \\
\hline $\mathrm{T} 7$ & $51 / \mathrm{F}$ & EPT non-functioning & Liver & $\mathbf{P}$ & - & - & ND \\
\hline $\mathrm{T} 8$ & $23 / \mathrm{F}$ & EPT non-functioning & Locally invasive & $\mathbf{P}$ & + & ++ & ND \\
\hline T9 & $50 / \mathrm{F}$ & EPT non-functioning & Locally invasive & $\mathbf{P}$ & +++ & - & ND \\
\hline $\mathrm{T} 10$ & $36 / F$ & EPT non-functioning & Liver & $\mathrm{P}+\mathrm{M}$ & +++ & +++ & ND \\
\hline T11 & $69 / \mathrm{F}$ & EPT non-functioning & Lymph node + liver & $\mathbf{P}$ & + & - & ND \\
\hline T12 & $50 / \mathrm{M}$ & EPT non-functioning & 0 & $\mathbf{P}$ & +++ & +++ & ND \\
\hline T13 & $55 / \mathrm{M}$ & EPT non-functioning & Liver & $\mathbf{P}$ & - & - & ND \\
\hline $\mathrm{T} 14$ & $47 / \mathrm{F}$ & EPT cacitonin producing & Liver & $\mathbf{P}$ & +++ & - & ND \\
\hline T15 & $60 / M$ & EPT cacitonin producing & 0 & $\mathbf{P}$ & - & - & ND \\
\hline
\end{tabular}

EPT = endocrine pancreatic tumour; $\mathrm{P}=$ primary tumour; $\mathrm{M}=$ metastases.

$\star_{-}$, no staining; + , weak staining; ++ , moderate staining, +++ , strong staining.

†Presence $(+)$ or absence $(-)$ of CD44 splice variants was determined by RT-PCR as described in the text.

noid were negative. However, the different patterns of expression of CD44 variants in these tumours were not investigated. Using reverse transcription PCR (RT-PCR) and immunohistochemistry, we have investigated the potential role of $\mathrm{CD} 44 \mathrm{H}$ and $\mathrm{CD} 44 \mathrm{v}$ as prognostic markers of aggressive behaviour in gastrointestinal carcinoids and pancreatic islet tumours.

\section{Methods \\ Tumours from 38 patients treated between 1986 and 1994, diagnosed at that time as hav- ing foregut endocrine neoplasms and gas- trointestinal carcinoids, were selected from the archives of the Department of Histopathology at Beaujon Hospital, Clichy. The details of the 25 patients with gastrinomas and endocrine pancreatic tumours are given in table 1 . Seven- teen tumours originated in the pancreas and eight others in the duodenal mucosa or from lymph nodes and comprised 10 gastrinomas, two insulinomas, three calcitonin producing tumours, and 10 clinically non-functioning islet cell carcinomas. The other 13 patients had carcinoid tumours, 11 of the midgut and two of the colon. Ten of these 13 patients had liver or lymph node metastases, or both. The diagnosis of neuroendocrine tumours was based on typi- cal histology and immunohistological positivity for neuroendocrine cell markers, such as Grimelius, neuron specific enolase and chro- mogranin A. Functioning tumours were diag- nosed by a compatible clinical syndrome asso- ciated with an increase in the serum concentrations of the corresponding hor- mones.}

\section{IMMUNOHISTOCHEMISTRY}

The presence of $\mathrm{CD} 44 \mathrm{H}$ and CD44 splice variants was detected immunohistochemically using the following monoclonal antibodies: $2 \mathrm{C} 5$ against haemopoietic or standard variant;
$3 \mathrm{G} 5$ against exon $\mathrm{v} 3$; 3D2 against exon $\mathrm{v} 4 / \mathrm{v} 5$; 2F10 against exon v6 (R\&D Systems, Abingdon, UK); and VFF-17 against exon v7 and part of exon v8 (Bender MedSystems, Vienna, Austria) of human CD44. A detailed description of these antibodies and their specificities has been published previously. ${ }^{16}{ }^{17}$ Immunohistochemistry was performed using a three-step immunoperoxidase technique on formalin fixed, paraffin wax embedded sections and on frozen sections where available. ${ }^{18}$ Frozen sections, $6 \mu \mathrm{m}$ thick, were fixed in cold acetone and stored at $-20^{\circ} \mathrm{C}$ pending analysis. The paraffin wax sections were pretreated in a microwave oven at $700 \mathrm{~W}$ in citrate buffer $\mathrm{pH}$ 6.2 ) for $3 \times 5$ minutes. Endogenous peroxidase activity was blocked by immersing the slides in $0.5 \%$ hydrogen peroxide in distilled water. All sections were then incubated with nonimmune goat serum to reduce non-specific background staining, with primary antibody for 40 minutes, and then with peroxidase labelled rabbit antimouse immunoglobulin (Dako, Copenhagen, Denmark) and swine antirabbit immunoglobulin (Dako). The colour reaction product was developped according to the method of Graham and Karnovsky. ${ }^{19}$ Staining was graded semiquantitatively as follows: no staining $(-)$ or a weak reaction $(+)$ in less than $10 \%$ of the tumours cells was scored as negative; staining in 10 to $50 \%$ of the cells as moderately positive $(++)$; and staining in more than $50 \%$ of the cells as strongly positive $(+++)$. Omission of the primary antibody was used as a negative control and a section of oesophageal squamous epithelium as a positive control for each monoclonal antibody.

RT-PCR

Fresh tissue samples were obtained following surgical resection from 16 patients with neuroendocrine tumours (five gastrinomas, 


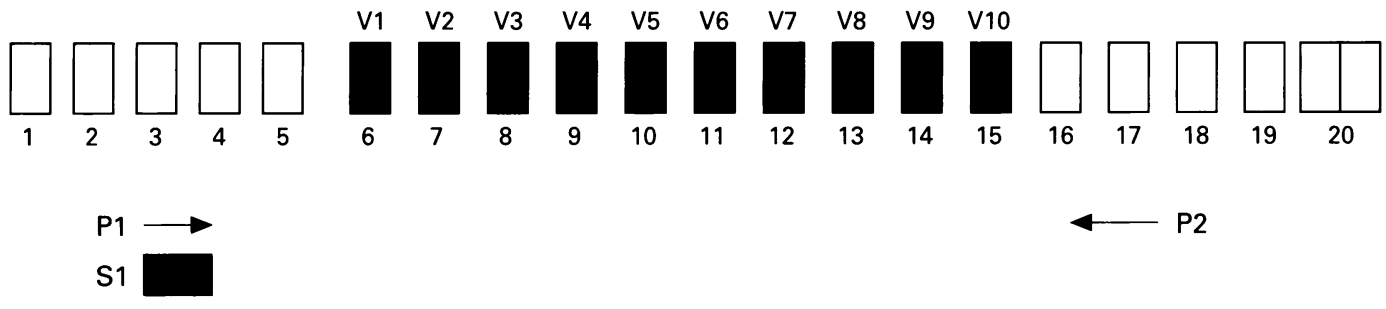

Figure 1 Schematic diagram of CD44 genomic DNA showing variant exons $v 1-v 10$ in black. The sequences of the PCR primers $P 1$ (sense) and $P 2$ (anti-sense) are as described by Matsumara and Tarin. ${ }^{9}$ The primers flank the insertion site at which variant exons $v 1-v 10$ can be included in the $m R N A$ transcript. The standard CD44 $m R N A$ transcript lacks $v 1-v 10$ and will result in a 482 bp RT-PCR product. Transcripts containing one or more of the variant exons will give rise to larger RT-PCR products. The $S 1$ probe is directed against exon 4 , which encodes part of the standard CD44 sequence. This probe will, in theory, detect all isoform products unless the exon 4 sequence is disrupted.

one insulinoma, three non-functioning endocrine pancreatic tumours, one calcitonin producing tumour, and seven carcinoid tumours). Normal pancreatic and liver tissue was obtained from the periphery of surgically resected specimens. Total cellular RNA was extracted from tumour tissue and reverse transcribed to cDNA using an avian myeloblastic virus reverse transcriptase and amplified using PCR. Conditions for PCR were as follows: $94^{\circ} \mathrm{C}$ for one minute, $55^{\circ} \mathrm{C}$ for one minute and $72^{\circ} \mathrm{C}$ for two minutes for 30 cycles. PCR primers (P1 and $\mathrm{P} 2$ ) and the $\mathrm{S} 1$ probe are equivalent to those used by Matsumara and Tarin. ${ }^{9} \mathrm{P} 1$ and P2 are located in the CD44 standard sequence directly flanking the variant region comprising exons 6 (v1) to 14 (v10) which are involved in alternative splicing (fig 1). Thus, the primers were designed to amplify any splicing variants of CD44. Negative controls, with no template cDNA in the reaction mixture, were run with every batch. In order to examine the quality and quantity of the cDNA used for PCR, $\beta$-actin was also amplified using primers recommended by Fujita et al..$^{20}$ The length of the probe generated by these primers is 368 base pairs (bp). In this system, a 500 bp fragment would be generated if genomic DNA contaminated the mRNA preparation.

SOUTHERN BLOT HYBRIDISATION

The amplification products were visualised under ultraviolet light after ethidium bromide staining and the CD44 products were subsequently transferred onto nylon membranes (Hybond $\mathrm{N}+$, Amersham, Little Chalfont, UK) for hybridisation with the ${ }^{32} \mathrm{P}$-labelled oligonucleotide probe $\mathrm{S} 1$. This probe, which anneals to the exon 4 region, detects all possible splice variants. Filters were exposed to Kodak $x$ ray film for 18 hours. This technique leads to the production of two fragments of 482 and 878 bp corresponding to standard and epithelial forms, respectively, and of several other fragments of large molecular weight if the sample contains alternatively spliced transcripts.

\section{Results}

IMMUNOHISTOCHEMISTRY

Normal adult human pancreas $(n=5)$ weakly expressed $\mathrm{CD} 44 \mathrm{H}$ on acini and on islet whereas few ductal epithelial cells displayed immunoreactivity with antibody directed against the epitope encoded by variant exon v6. Staining was present on the cell membrane and no difference was observed between paraffin wax and frozen specimens. Table 1 summarises the results of $\mathrm{CD} 44 \mathrm{H}$ and CD44v6 expression in gastrinomas and pancreatic endocrine tumours. Nine of the 10 gastrinomas and seven of the 15 other pancreatic
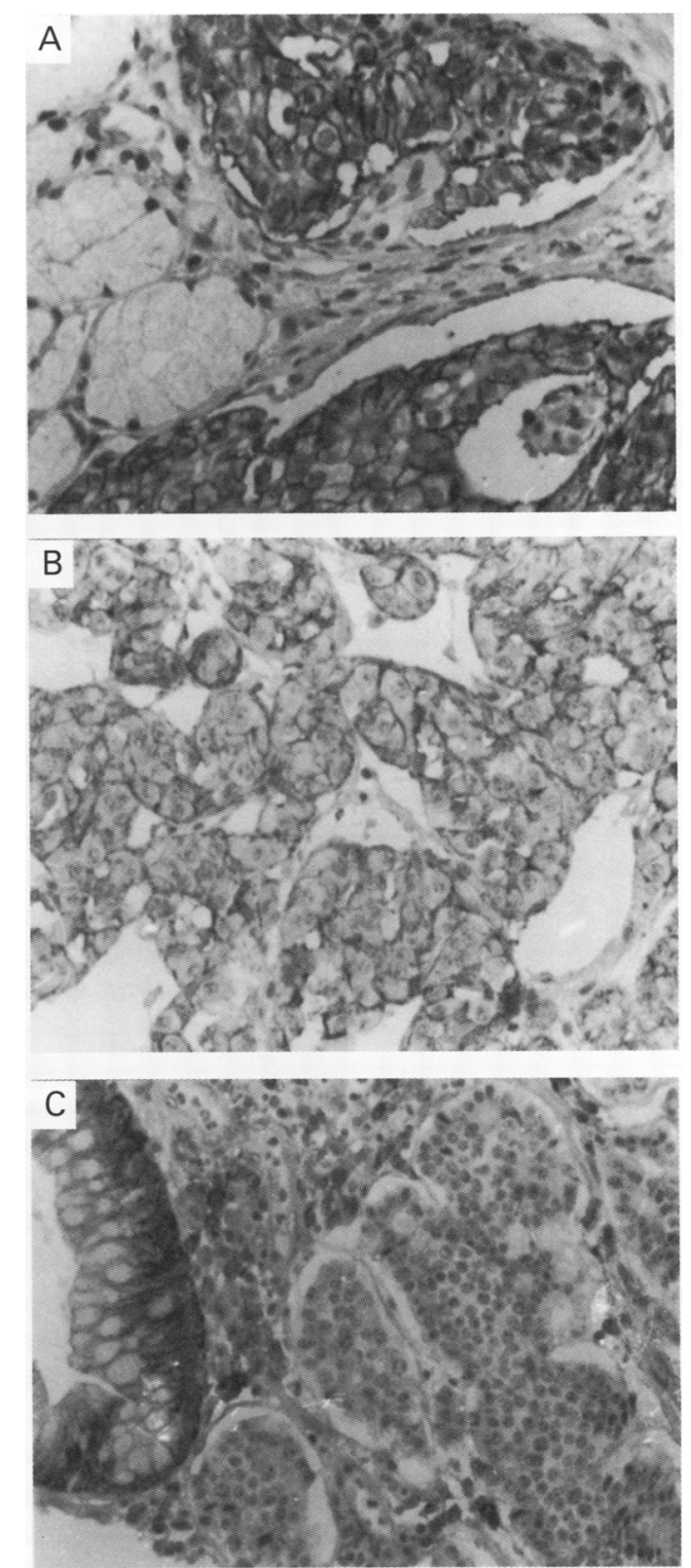

Figure $2 C D 44 H$ expression in three tumour types. $A$ duodenal gastrinoma $(A)$ and an insulinoma $(B)$ display a diffusely positive reaction with the two antibodies. In a midgut carcinoid tumour (C), however, only the stromal cells are positive for $C D 44 H$, while the tumour cells are unstained. 
neuroendocrine tumours were CD44v6 positive. Most of the tumours with CD44v6 expression were also positive for $\mathrm{CD} 44 \mathrm{H}$ (table 1). Two non-functioning pancreatic tumours expressed $\mathrm{CD} 44 \mathrm{H}$ only. In contrast to gastrinomas, in which staining was usually strong and diffuse, heterogeneous staining was observed in positive neuroendocrine pancreatic tumours (figs 2 and 3 ). No staining was seen with the antibodies directed against the v3, v4-v5 and v7-v8 exons. In contrast, only one midgut carcinoid among the 11 carcinoid tumours analysed was positive for $\mathrm{CD} 44 \mathrm{H}$ and exon v6. However, strong expression of $\mathrm{CD} 44 \mathrm{H}$ and exon v6 was detected on the two neuroendocrine carcinomas of the colon. Staining for CD44H was observed in the stromal component of all neuroendocrine tumours but seemed to be more pronounced in midgut carcinoid tumours (figs 2 and 3). No statistically significant association was found between
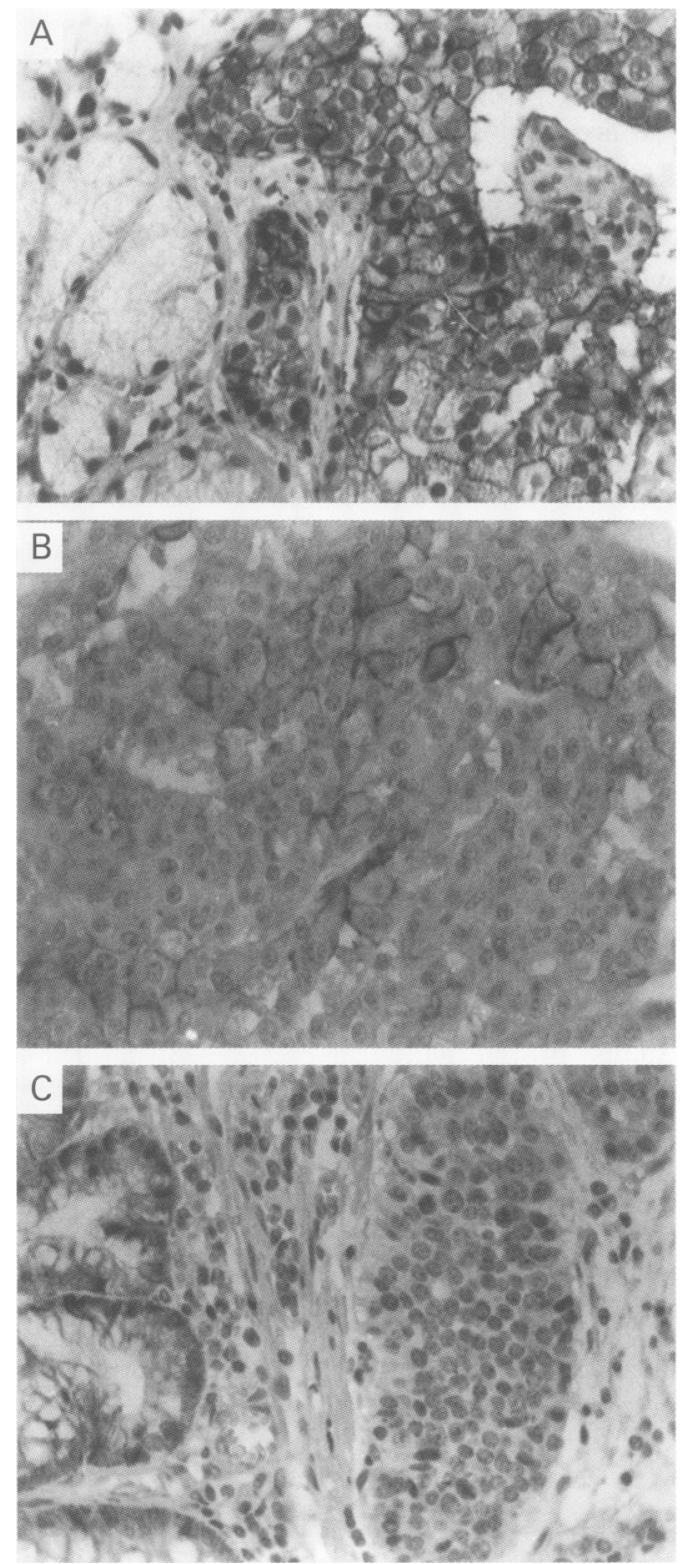

Figure 3 CD44v6 expression in three tumour types. $A$ duodenal gastrinoma $(A)$ and an insulinoma $(B)$ display a diffusely positive reaction with the two antibodies. In a midgut carcinoid tumour (C), however, no immunostaining was observed.
CD44v6 expression and the presence of lymph node $\left(\chi^{2} ; \mathrm{p}=0.82\right)$ or hepatic metastases $(\mathrm{p}=$ $0.14)$.

EXPRESSION OF CD44 MRNA

All PCR products from the 16 different tumours analysed contained at least one 480 bp fragment of the CD44 standard form (fig 4). In normal pancreas, standard and epithelial (878 bp) forms of CD44 were observed. Four of five gastrinomas, three of five other endocrine pancreatic tumours (one insulinoma and two non-functioning tumours) and a colonic neuroendocrine carcinoma produced longer hybridised fragments than the epithelial form, which corresponded to splice variants (fig 4). By contrast, the epithelial form and splice variants of CD44 were not detected in midgut carcinoids, even after exposing the blots for 72 hours. Interestingly, compared with normal pancreas, the epithelial form of CD44 was not detected immunohistochemically in midgut carcinoid tumours. All tumours with large splice variants expressed CD44v6 (fig 3). The detection of CD44H mRNA in midgut carcinoid tumours lacking expression on tumour cells by immunohistochemistry is probably due to the strong positivity of the stromal component. PCR of $\beta$-actin primers demonstrated that the amount and quality of mRNA did not differ significantly among samples.

\section{Discussion}

Recently, there have been many reports on the role of CD44v in primary tumours and their metastases. In breast and colorectal cancers, the expression of CD44 variants encoding exon $v 6$ has been linked to tumour dissemination and cancer metastases. ${ }^{9}{ }^{13}{ }^{21}$ Interestingly, the percentage of tumour cells positive for exon v6 increased during neoplastic transformation of colorectal adenoma, in parallel with changes in p53 tumour suppressor gene. ${ }^{22}$ Whereas CD44v6 expression was also correlated to aggressive non-Hodgkin's lymphoma, ${ }^{14}$ in metastatic gastric carcinoma both CD44-v5 and v9 seem to be expressed preferentially. ${ }^{23-25}$ In contrast, loss of CD44 expression was found in endometrial carcinoma with high metastatic potential. ${ }^{20}$ Thus, the function of CD 44 in the development of metastases is complex and interpretation of CD44 variant expression in tumours must be compared with the pattern observed in the corresponding normal tissue. ${ }^{16}$

In the present study diffuse and strong staining was found for CD44H and CD44v6 in all gastrinomas except one. In contrast to the only study performed on endocrine tumours of the gut, ${ }^{15}$ we also observed increased expression of $\mathrm{CD} 44 \mathrm{H}$ or CD44v6, or both, in several other endocrine tumours of the pancreas. Insulinomas, which are usually regarded as benign tumours, were positive in our two cases. In contrast, there was a pronounced difference in the pattern of expression of the CD44H and v6 epitopes in the endocrine tumours and the midgut carcinoid tumours. There was no evidence of CD44 expression among 10 of the 11 midgut carcinoid tumours analysed. These results are in agreement with those of 

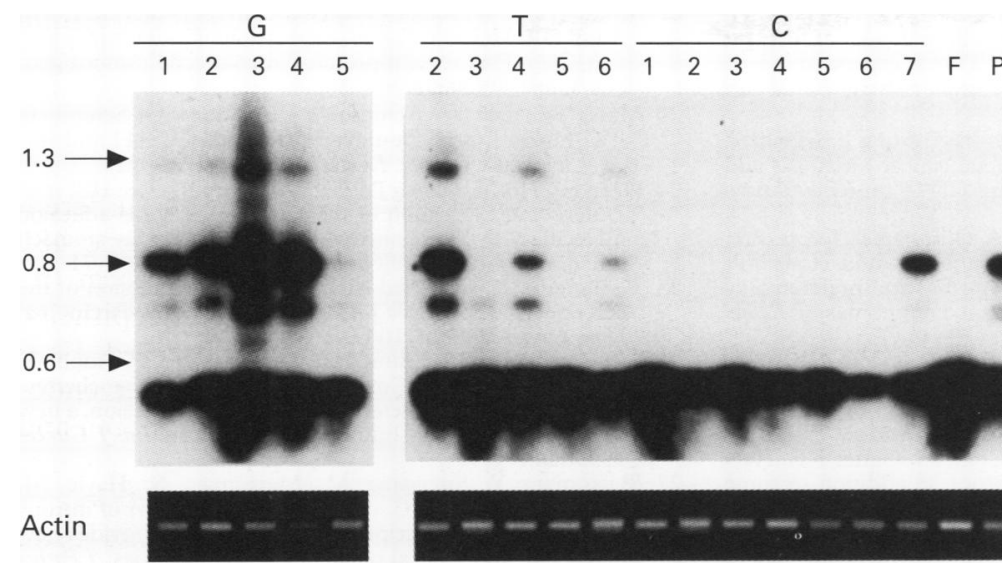

Figure 4 Detection of CD44 mRNA in neuroendocrine tumours of the gastrointestinal tract. The lower bands estimated at 489 base pairs corresponding to the expected standard CD44 amplification product were present in all specimens. Epithelial forms and splice variants were detected only in some gastrinomas and endocrine pancreatic tumours (EPT). Lanes G1-G4, gastrinomas; lane T2, insulinoma; lanes T3-T5, non-functioning EPT; lane T6, calcitonin producing EPT; lanes C1-C6, midgut carcinoid tumours; lane C7, neuroendocrine carcinoma of the colon; $F$ and $P$, normal liver and pancreas, respectively.

Chaudhry et al. ${ }^{15}$ Interestingly, CD44v6 was expressed strongly in the two cases of neuroendocrine carcinoma of the colon, a tumour known to have a poor prognosis. The CD44v3, CD44v4-v5 and CD44v7-v8 isoforms were not detected.

In cases studied both by RT-PCR and immunohistochemistry, we observed a good correlation between the presence of large CD44 mRNA transcripts and expression of CD44v6. This observation is in accordance with a recent study performed on human breast tumours. ${ }^{26}$ However, in our series, although most gastrinomas or other endocrine pancreatic tumours expressed epithelial forms by RT-PCR, we found no expression of CD44v7-v8 by immunohistochemistry. There are three possible explanations for this observation. First, either these epitopes were concealed, because epithelial fragments display numerous glycosylation sites or, second, there was preferential expression of $\mathrm{v} 9-\mathrm{v} 10$ epithelial exons which were not studied here by immunohistochemistry. Third, immature mRNA transcripts containing introns may have accumulated. These transcripts, which give a smear pattern on Southern blots, were described initially in bladder cancer. ${ }^{27}$ The clinical significance of the smear pattern observed in some gastrinomas warrants further study.

The insertion of various exons into the CD44 molecule decreases the ability of CD44 to serve as a hyaluronate receptor and thus confers metastatic potential on cancer cells. ${ }^{28} 29$ As in other tumours, generation of CD44 splice variants is probably involved in islet cell tumorigenesis. However, our study suggests that expression of these splice variants is not related to lymph node or hepatic metastases. Such results are in contrast to previous observations in other types of cancer and in the only published report on endocrine pancreatic tumours. ${ }^{15}$ In the latter study, liver metastases were encountered more often in CD44 negative endocrine tumours.

Although the lack of expression of CD44 in midgut carcinoid tumours is further evidence that these tumours and endocrine pancreatic tumours are unrelated, it is possible that low level expression of CD44 reduces adhesion between cells, permitting detachment of proliferative cells from primary sites. Previous studies supporting this inverse relation between tumour progression and low $\mathrm{CD} 44 \mathrm{H}$ expression have been reported for neuroblastoma, carcinoma of the ovary and small cell carcinoma of the lung. ${ }^{30-32}$

The loss of CD44E in midgut carcinoid tumours may also affect a number of biological functions. The CD44E isoform, which contains exons v8, v9 and v10 inserted into the $\mathrm{CD} 44 \mathrm{H}$ transcript, has extensive $\mathrm{O}$ - and $\mathrm{N}$-linked glycosylation sites. ${ }^{33} \mathrm{CD} 44$ glycans have been implicated in the binding of growth factors and in the modulation of the cell's adhesive function. Furthermore, it has been demonstrated that endocrine pancreatic tumours are capable of expressing multiple growth factor peptides-for example, platelet derived growth factor and transforming growth factor $\alpha$ or $\beta .^{6}$ Therefore, it is possible that loss of $\mathrm{CD} 44 \mathrm{E}$ expression leads to impaired contact between cells, thereby contributing to tumour growth and invasion. Future studies will be required to evaluate this hypothesis further.

In conclusion, the pattern of CD44 expression differs in midgut carcinoid and pancreatic islet tumours, raising the possibility that the contribution by CD44 to tumour progression differs in these tumours. However, variant forms of CD44 do not add to histological evaluation in identifying aggressive endocrine pancreatic tumours. The functional roles of the standard and variant forms of the CD44 gene products in neuroendocrine digestive tumours remain to be determined.

This work was supported by a grant from the Sociéte Nationale Française de Gastroentérologie.

1 Klöppel G, Heitz PU. Pancreatic endocrine tumours. Pathol Res Pract 1988;183:155-8.

2 Kenny BD, Sloan JM, Hamilton PW, Watt PCH, Johnston $\mathrm{CF}$, Buchanan $\mathrm{KD}$. The role of morphometry in predicting prognosis in pancreatic endocrine tumours. Cancer 1989;64:460-5.

3 Pelosi G, Zamboni G, Doglioni C, Rodella S, Bresaola E, Iacono $\mathrm{C}$, et al. Immunodetection of proliferating cell nuclear antigen assesses the growth fraction and predicts malignancy in endocrine pancreatic tumours of the pancreas. Am F Surg Pathol 1992;16:1215-25.

4 Von Herbay A, Sieg B, Schürmann G, Hofmann WJ, Betzler M, Otto HF. Proliferative activity of neuroendocrine tumours of the gastroenteropancreatic endocrine system: DNA flow cytometric and immunohistological investigations, Gut 1991;32:949-53.

5 Metz DC, Kuchnio M, Fraker DL, Venzon DJ, Jaffe G, Jensen RT, et al. Flow cytometry and Zollinger-Ellison syndrome: Relationship to clinical course. Gastroenterology 1993;105:799-813.

6 Chaudhry A, Öberg K. Expression of growth factor peptides and adhesion molecules in endocrine pancreatic tumours. In: Mignon M, Jensen RT, eds. Endocrine tumours of the pancreas. Front Gastrointestinal Res. Vol 23. Basel: Karger, 1994:132-46.

7 Gunthert U, Hofman R, Rudy W, Reber S, Zoller M, Haubmann I, et al. A new variant of glycoprotein CD44 confers
metastatic potential to rat carcinoma cells. Cell 1991; 65:13-24.

8 Seiter S, Arch R, Reber S, Komitowski K, Hofman M, Ponta $\mathrm{H}$, et al. Prevention of tumour metastasis formation by $\mathrm{H}$, et al. Prevention of tumour metastasis form

9 Matsumura Y, Tarin D. Significance of CD44 gene products for cancer diagnosis and disease evaluation. Lancet for cancer diagn

10 Tanabe KK, Ellis LM, Saya H. Expression of CD44R1 adhesion molecule in colon carcinomas and metastases. Lancet 1993;341:725-6.

11 Finn L, Becich M, Dougherty G, Finley G, Meisler A, Cooper D. CD44 alternative splicing in human colon carcinomas. Lab Invest 1993;68: 49A. 
12 Heider $\mathrm{KH}$, Hofmann $\mathrm{M}$, Van den Berg $\mathrm{F}$, Ponta $\mathrm{H}$, Herrlich P, Pals ST. A human homologue of the rat metastasis-associated variant of CD44 is expressed in col-
orectal carcinomas and adenomatous polyps. 7 Cell Biol orectal carcinomas
$1993 ; 120: 227-33$.

13 Mulder JWR, Kruyt PM, Sewnath M, Oosting J, Seldenrijk $\mathrm{CA}$, Weidema WF, et al. Colorectal cancer prognosis and expression of exon-v6-containing CD44 proteins. Lancet 1994;344:1470-2.

14 Terpe HJ, Koopmann R, Imhof BA, Günthert U. Expression of integrins and CD44 isoforms in non-Hodgkin's lymphomas: CD44 variant isoforms are preferentially as: CDA4 variant isoforms are preferentially expressed in high-

15 Chaudhry A, Gobl A, Eriksson B, Skogseid B, Öberg K. Different splice variants of CD44 are expressed in gastrinomas but not in other subtypes of endocrine pancreatic tumours. Cancer Res 1994;54:981-6.

16 Fox SB, Fawcett J, Jackson DG, Collins I, Gatter KC, Harris AL, et al. Normal human tissues, in addition to some tumours, express multiple different CD44 isoforms. Cancer Res 1994;54:4539-46.

17 Koopman G, Heider KH, Horst E, Adolf GR, Van Den Berg $\mathrm{F}$, Ponta F, et al. Activated human lymphocytes and aggressive non-Hodgkin's lymphomas express a homologue of the rat metastasis-associated variant of CD44. 7 logue of the rat metastasis-ass
Exp Med 1993;177:897-904

18 Mason DY, Sammons RE. The labelled antigen method of immunoenzymatic staining. F Histochem Cytochem 1979; 27:832-40.

19 Graham RC, Karnovski MJ. The early stages of absorption of horseradish peroxidase in the proximal tubules of mouse kidney: ultrastructural cytochemistry by a new technique. F Histochem Cytochem 1966;14:291-302.

20 Fujita N, Yaegashi N, Ide Y, Sato S, Nakamura M, Ishiwata I, et al. Expression of CD44 in normal human versus tumour endometrial tissues: possible implication of reduced expression of CD44 in lymph-vascular space involvement of cancer cells. Cancer Res 1994;54:3922-8.

21 Kaufmann M, Heider KH, Sinn HP, Minckwitz G, Ponta H, Herrlich P. CD44 variant epitopes in primary breast cancer and length of survival. Lancet 1995;345:615-19.
22 Mulder JWR, Wielenga VJM, Polak MM, van den Berg FM, Adolf GR, Herrlich P, et al. Expression of mutant p 53 protein and CD44 variant proteins in colorectal tumourigenesis. Gut 1995;36:76-80.

23 Mayer B, Jauch KW, Günthert U, Figdor CG, Schildberg FW, Funke I, et al. De-novo expression of CD44 and survival in gastric cancer. Lancet 1993;342:1019-22.

24 Harn HJ, Ho LI, Chang JY, Wu CW, Jiang SY, Lee HS, et al. Differential expression of the human metastasis adhesion molecule CD44v in normal and carcinomatous stomach mucosa of chinese subjects. Cancer 1995;75:1065-71

25 Washington K, Gottfried MR, Telen MJ. Expression of the cell adhesion molecule CD44 in gastric adenocarcinoma. Hum Pathol 1994;25:1043-9.

26 Dall P, Heider KH, Sinn HP, Skroch-Angel P, Adolf G, Kaufmann $M$, et al. Comparison of immunohistochemistry and RT-PCR for detection of CD44v-expression, a new prognostic factor in human breast cancer. Int $\mathcal{F}$ Cancer 1995;60:471-7.

27 Matsumara Y, Sugiyama M, Matsumara S, Hayle AJ, Robinson P, Smith JC, et al. Unusual retention of introns in CD44 gene transcripts in bladder cancer provides new diagnostic and clinical oncological opportunities. 7 Pathol 1995;177:11-20.

28 Sy MS, Guo YJ, Stamenkovic I. Distincts effect of two CD44 isoforms on tumour growth in vivo. $\mathcal{F}$ Exp Med CD44 isoforms o

29 Thomas L, Byers HR, Vink J, Stamenkovic I. CD44H regulates tumour cell migration on hyaluronate-coated substrate. F Cell Biol 1992;118:971-7.

30 Cannistra SA, Kansas GS, Niloff J, DeFranzo B, Kim Y, Ottensmeier C. Binding of ovarian cancer cells to peritoneal mesothelium in vitro is partly mediated by CD44H. Cancer Res 1993;53:3830-8.

31 Shtivelman E, Bishop JM. Expression of CD44 is repressed in neuroblastoma cells. Mol Cell Biol 1991;11:5446-53.

32 Penno MB, Thomas August J, Baylin SB, Mabry M, Ilona Linnoila R, Lee VS, et al. Expression of CD44 in human linnoila R, Lee VS, et al. Expression of CD

33 Iida N, Bourguignon LYW. New CD44 splice variants associated with human breast cancers. F Cell Physiol 1995; 162:127-33. 